\title{
Distribution and Mobility of Arsenic Species in Solids and Leachate Composts
}

\author{
S. Hamida ${ }^{1 *}$, F. Laborda ${ }^{2}$, G. Cepria ${ }^{2}$ and D. Benouali ${ }^{3}$ \\ ${ }^{1}$ University Center of Belhadj Bouchaib-Ain Temouchent-Algeria. \\ ${ }^{2}$ IUCA, Group of Analytical Spectroscopy and Sensors -University of Zaragoza Spain. \\ ${ }^{3}$ Faculty of Chemistry, Department of Physical Chemistry USTO- Algeria. \\ *Corresponding Author Email: sahnounia@yahoo.es \\ Received 09 September 2016, Revised 16 November 2016, Accepted 08 December 2016
}

\begin{abstract}
Because arsenic can exist in toxic and non-toxic forms, it is important to identify them in compost. This organic material prepared from urban and agricultural wastes, is often used for recovering or remedying soils. As a matter of fact, it's important to control the mobility of arsenic and its different forms present in leachate composts. In this work total arsenic was determined in compost samples, previously submitted to acid digestion using Inductively Coupled Plasma Mass Spectroscopy (ICP-MS). Total inorganic arsenic and As(III) results were compared with those directly determined in solids samples by Square Wave Voltammetry (SWV). It was found that two thirds of arsenic present in solids are in inorganic forms. As(III) is a minor component in the solid, detectable only in agricultural composts. In leachates, the inorganic arsenic was mobilized in his majority as As(III).
\end{abstract}

Keywords: Compost, Total arsenic, Inorganic arsenic, As(III), ICP-MS, Leachate, Mobility.

\section{Introduction}

Arsenic is a toxic substance that seriously affects human health. That's why its limits in the environment, food and drinking water have been legally established. The World Health Organization (1993) guidelines for drinking water quality, recommend a maximum concentration of total arsenic of $10 \mu \mathrm{gL}^{-1}$. On the other hand the European Union (2001) recommend a maximum concentration of total arsenic in compost according (Final report, 2004, commission europea Proyecto ENV.A.2/ETU/2001/24). The quality of compost in Spain is regulated by fertilizing law (Real decreto 506/2013 28 June for fertilizing products), but does not include arsenic concentrations as heavy metal. As a consequence, the appropriate analytical methods must be used to detect lower concentrations of arsenic. Many detection methods have been developed for determination of such lower levels [1,2]. These include Inductively Coupled Plasma Mass Spectrometry (ICP-MS), which can reach limits of detection $0.0006 \mu \mathrm{g} \mathrm{L}^{-1}$ in a solution that is continuously introduced at about $1 \mathrm{mLmin}^{-1}$ with standard sample introduction via a nebulizer and spray chamber. ICP-MS is very used in the determination of arsenic, but the biggest drawback is possible interference due to the presence of chlorine in samples. This interference can be avoided by separation of the element from the matrix as a hybrid or by using plasma mixture of argon and nitrogen [3-6]. Arsine has been generated by chemical processes using tetrahydroborate in acid medium with ICP-MS or electrochemically in the cathode space of an electrochemical cell designed for that purpose [79]. It has also been emphasized that, the integration of continuous flow separation: Liquid Chromatography Inductively Coupled PlasmaMass Spectrometry (HPLC/ICP-MS) makes the method more effective. A further improvement of the method is the use of reaction/collision cell 
technology. In our work we are also interested by the electrochemical technique, Anodic Stripping Voltammetry (ASV) successfully used by Radke et. al., [10]. This method has the ability to detect and measure only inorganic arsenic species but at sub values of the order of $\mu \mathrm{gL}^{-1}$, because it is not possible to integrate a continuous separation method needed for speciation analysis.

Arsenic in aqueous solution can be found in oxidation condition state; As (III) as arsenious acid $\mathrm{HAsO}_{2}$ in reductor conditions until $\mathrm{pH}=9$ and As (V) as arsenic acid $\mathrm{H}_{3} \mathrm{AsO}_{4}$ at $\mathrm{pH}$ less than 2 [11-13]. Inorganic arsenic is the most toxic in the United States Environmental Protection Agency (USEPA) list of prioritized pollutants and classified as Group I carcinogens based on human epidemiological data, while the methylated As species such as monomethylarsinic acid (MMA) and dimethyarsinic acid (DMA) are less toxic, arsenobetaine (AsB), arsenocholine (AsC) and other arsenosugars are even considered to be of no toxicity [2]. The toxicity of arsenic depends on his chemical form; As (III) is 5 to 8 times more toxic than As (V). Recent data suggest the following order in terms of arsenic toxicity: MMA (III) $>$ As (III) > As (V) > DMA (V) > MMA (V) [14].

The mobility of arsenic species in aqueous medium is limited by his adsorption on iron oxides, aluminum, and manganese. This adsorption occurs in oxidants conditions and acid $\mathrm{pH}$, where As (V) adsorption is more favorable than As (III). This latter is more soluble, toxic and mobile than As (V), and able to migrate to aquifers [15]. The compost is applied for the recovering or remedying soils, and will be affected by the weather process (rain and irrigation). These conditions will mobilize arsenic present in the solid, according to the chemical form and physical-chemical interactions with other components. For this reason leachate operations were carried out to simulate natural mobilization, and the results obtained will indicate the mobilized fraction from compost to plants and aquifers $[16,17]$. The main purpose of this paper is the speciation of different forms of arsenic in composts and leachates by ICP-MS which offers excellent sensitivity, wide linear dynamic range, isotope-specific detection capabilities, and fast detection. The mobility of As
(III) and As (V) in solids and leachate composts were also discussed, and those results were compared to results obtained by SWV.

\section{Experimental and Methods \\ Reagents and samples}

The acid digestion of samples composts was achieved by microwave with EPA 3051 method [18]. The leaching was carried out with the method of Kosson et al., Col. for characterizing the mobilization of contaminants in residues [19]. The centrifugation was done with the membrane PVDF (Durapore, Millipore) $0.45 \mu \mathrm{m}$. Urban compost USRC3 was obtained by anaerobic digestion followed by composting. Urban compost USRC6 was obtained by only composting. The compost agromat $\mathrm{CP}-1$ is the reference material. All the chemicals used in this work were analytical-grade reagents, $\mathrm{HNO}_{3}, \mathrm{HCl}$ purchased from Baker and Merck. Internals patrons of: arsenic $994 \mathrm{mgL}^{-1}$, rhodium $10 \mathrm{mgL}^{-1}$, indium $1000 \mathrm{mgL}^{-1}$ and germanium $1000.6 \mathrm{mgL}^{-1}$ were purchased from Fluka. Copper patron $1006 \mathrm{mgL}^{-1}$ was purchased from Aldrich. Argon was used as collision gas and the instrumental parameters of ICP-MS were optimized with the use of indium (In) as internal standard. The conditions are indicated in Table 1.

\section{Results and Discussion \\ Determination of arsenic in compost}

Around $0.4 \mathrm{~g}$ of ground compost samples were weighed and $10 \mathrm{~mL}$ of concentrate $\mathrm{HNO}_{3}$ was added, then submitted with the target to assisted acid digestion microwave, following EPA 3051 method indicated in Table 2.

For the analysis of digested compost samples and target with ICP-MS, $5 \mathrm{~mL}$ of each one was diluted to $50 \mathrm{~mL}$ with $\mathrm{HNO}_{3}(1 \%)$. The determination of arsenic was achieved by external calibration between $0.1 \mu \mathrm{gL}^{-1}$ and $100 \mu \mathrm{gL}^{-1}$. The limits of detection were $0.01 \mu \mathrm{gL}^{-1}$. The results of analysis of compost samples are regrouped in Table 3. The results obtained with reference material are in agreement with certified results and therefore validates our digestive procedure and analysis for the determination of total arsenic in compost samples. 
Table 1. Optimized instrumental parameters of ICP-MS.

\begin{tabular}{l|c}
\hline Parameter & Value \\
\hline Power RI & $1150 \mathrm{~W}$ \\
\hline Rate of flow Ar & $15 \mathrm{~L} \cdot \mathrm{min}^{-1}$ \\
External & $1.2 \mathrm{~L} \cdot \mathrm{min}^{-1}$ \\
Intermediate & $0.9 \mathrm{~L} \cdot \mathrm{min}^{-1}$ \\
Nebulizer & $1.2 \mathrm{~L} \cdot \mathrm{min}^{-1}$ \\
Rate of flow sample & \\
\hline Collision cell/reaction & \\
Rate flow Ar & \\
Rpq & $0.4 \mathrm{~L} \cdot \mathrm{min}^{-1}$ \\
Rpa & 0.5 \\
& 0 \\
\hline
\end{tabular}

\section{Determination of arsenic in lixiviates composts}

Leachate compost samples were obtained by adding $400 \mathrm{~mL}$ of ultrapure water to $40 \mathrm{~g}$ of compost samples without grounding. The reference compost agromat $\mathrm{CP}-1$ material was prepared by adding $40 \mathrm{~mL}$ ultrapure water to $4 \mathrm{~g}$ of $\mathrm{CP}-1$. All samples were kept in airtight containers and submitted to rotary agitator with a velocity of $28 \pm 2$ $\mathrm{rpm}$ during $48 \mathrm{~h}$ at atmospheric temperature. Then the supernatant was stirred at $4000 \mathrm{rpm}$ during 10 min, and filtrated with PVDF (Durapore, Millipore) $0.45 \mu \mathrm{m}$ membrane. The filtrate leachate was guarded in polyethylene tube in the refrigerator at $4^{\circ} \mathrm{C}$ for using later. For the determination of total arsenic in leachate compost samples, $5 \mathrm{~mL}$ of these latter were subjected to assisted microwave acid digestion, based on the EPA 3015 method indicated in the Table 2.

Table 2. Program of microwave acid digestion.

\begin{tabular}{l|c|c|c}
\hline $\begin{array}{c}\text { Power } \\
\text { W }\end{array}$ & $\begin{array}{c}\text { Ramp } \\
\text { Min }\end{array}$ & $\begin{array}{c}\text { Temperature } \\
{ }^{\circ} \mathbf{C}\end{array}$ & $\begin{array}{c}\text { Stay } \\
\text { Min }\end{array}$ \\
\hline $1600^{\mathrm{a}}$ & $2^{\mathrm{a}}$ & $165^{\mathrm{a}}$ & $0^{\mathrm{a}}$ \\
$1600^{\mathrm{a}}$ & $3^{\mathrm{a}}$ & $175^{\mathrm{a}}$ & $5^{\mathrm{a}}$ \\
$1600^{\mathrm{b}}$ & $10^{\mathrm{b}}$ & $160^{\mathrm{b}}$ & $0^{\mathrm{b}}$ \\
$1600^{\mathrm{b}}$ & $10^{\mathrm{b}}$ & $170^{\mathrm{b}}$ & $0^{\mathrm{b}}$ \\
\hline
\end{tabular}

a: program of EPA 3051 method b: program of EPA 3015 method

The digested leachates were traversed in a polyethylene tube, and carried to $50 \mathrm{~mL}$ with $1 \%$ of $\mathrm{HNO}_{3}$. For the total arsenic determination by ICP-MS, $5 \mathrm{~mL}$ of previous dissolution were diluted at $25 \mathrm{~mL}$ with $1 \%$ of $\mathrm{HNO}_{3}$. For the determination of total arsenic in leachate composts, $5 \mathrm{~mL}$ of these lixiviated and digested samples were diluted to 25
$\mathrm{mL}$ with $1 \% \mathrm{HNO}_{3}$. The results of analysis by ICPMS are regrouped in the Table 3.

Table 3. Total arsenic in composts and leachates by ICP-MS (n=3).

\begin{tabular}{l|c|c|c|c}
\hline Sample & $\begin{array}{c}\text { Total leachate } \\
\text { arsenic } \text { mgkg }^{-1}\end{array}$ & $\begin{array}{c}\text { Total leachate } \\
\text { arsenic \% }\end{array}$ & $\begin{array}{c}\text { Total As } \\
\text { mgkg }^{-1}\end{array}$ & $\begin{array}{c}\text { Certified } \\
\text { value } \\
\text { mgkg }^{-1}\end{array}$ \\
\hline CP-1 & $0.186 \pm 0.005$ & 3 & $5.72 \pm 0.06$ & $5.5 \pm 1.9$ \\
USRC3 & $0.894 \pm 0.010$ & 23 & $3.84 \pm 0.22$ & \\
USRC6 & $0.846 \pm 0.010$ & 30 & $2.87 \pm 0.03$ & \\
\hline
\end{tabular}

The percentage of arsenic that may be lixiviated and mobilized is less than in agricultural compost (3\%) than urban compost USRC3 and USRC6 (20-30\%). Although the concentration of total arsenic in solid compost CP-1 is high, however its leachate concentration is smaller than that in USRC 3 and USRC6 composts. The urban composts present a bigger proportion of soluble species.

\section{Distribution of As(III) and As(V) species in solids and leachate composts}

In Table 4, compared results of total arsenic in digested samples by ICP-MS and total inorganic arsenic (As (III) + As (V)), determined in solids samples by immobilized particle SWV are recapitulated.

Table 4. Total arsenic determined by ICP-MS compared to inorganic arsenic and As (III) determined by SWV.

\begin{tabular}{lccccc}
\hline Solid & $\begin{array}{c}\text { As total } \\
\text { mgkg }^{-1}\end{array}$ & $\begin{array}{c}\text { As } \\
\text { inorganic } \\
\text { mgkg }^{-1}\end{array}$ & $\begin{array}{c}\text { As(III) } \\
\text { mgkg }^{-1}\end{array}$ & $\begin{array}{c}\text { As } \\
\text { inorganic } \\
\text { \% }\end{array}$ & $\begin{array}{c}\text { As(III) } \\
\text { \% }\end{array}$ \\
\hline CP-1 & $5.72 \pm 0.06$ & $4.08 \pm 0.11$ & $1.29 \pm 0.41$ & 71 & 23 \\
USRC3 & $3.84 \pm 0.22$ & $2.51 \pm 0.49$ & $<0.3$ & 65 & - \\
USRC6 & $2.87 \pm 0.03$ & $1.78 \pm 0.05$ & $<0.3$ & 62 & - \\
\hline
\end{tabular}

Detailed study of $\mathrm{pH}$ influence on the reduction of As $(\mathrm{V})$, shown that in linear sweep voltammetry, voltammograms of As (V) are noisy due to the dissolution of iron oxides in the strongly acid medium as shown in the Fig. 1. The effect of acidity was also significant and depends on the pre-treatment and stripping process on $\mathrm{pH}$ as shown in the Table 5. The peak at $0.6 \mathrm{~V}$ was shifted anodically with decreasing acid concentration, but the peak at $0.2 \mathrm{~V}$ shifted in the 
opposite direction. Both peaks disappeared in 0.1 $\mathrm{M}$ acetic acid-acetate buffer $(\mathrm{pH}=5)$. So, it is possible to reduce electrochemically As (V) in $1 \mathrm{M}$ $\mathrm{HCl}$ in the presence of hematite and avoiding the use of chemical reducing agents [20]. Taking advantage of this fact, the selective reduction of As (III) and of total inorganic arsenic can be accomplished by selecting the adequate pHs. As (III) can be reduced to $\mathrm{As}^{\circ}$ in $0.1 \mathrm{M}$ acetic acidacetate buffer, however both As (III) and As (V) are reduced in $1 \mathrm{M} \mathrm{HCl}$, provided that the applied potential is lower than $-0.8 \mathrm{~V}$.

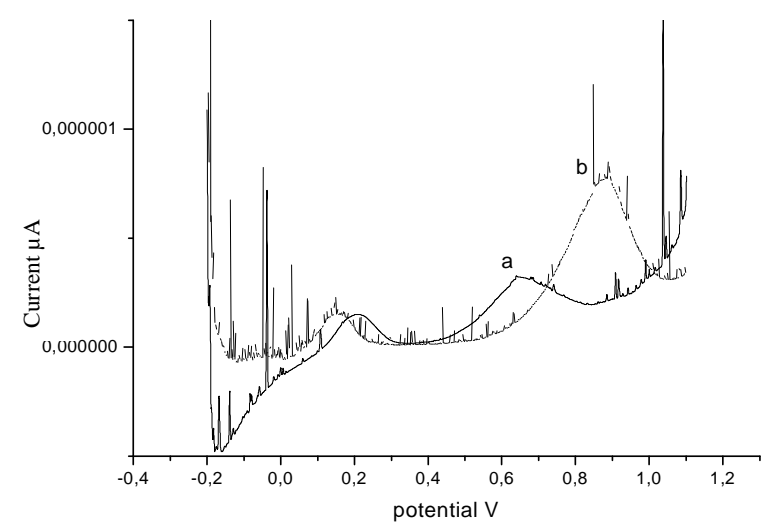

Figure 1. Influence of $\mathrm{pH}$ on the signal of a solid mixture of $\mathrm{As}_{2} \mathrm{O}_{5}$ : Hematite: $\mathrm{SiO}_{2}$ 2:2:96 $(\mathrm{w} / \mathrm{w})$ at pretreatment $-1 \mathrm{~V}$ ss and scan speed $10 \mathrm{Mv} \mathrm{s}^{-1}$ a: $\mathrm{HCl} 1 \mathrm{M}$ b: $\mathrm{HCl} 4 \mathrm{M}$

Table 5. Influence of the prea-treatment potential and the media on the stripping peaks potential and number of peaks of a solid sample $\mathrm{As}_{2} \mathrm{O}_{5}$ : Hematite: $\mathrm{SiO}_{2}$ (2:2:96).

\begin{tabular}{lcccc}
\hline & $\begin{array}{c}\text { Pre- } \\
\text { tratment }\end{array}$ & $\begin{array}{c}\text { Potential } \\
(\mathbf{V}) \mathbf{5 s}\end{array}$ & & \\
\hline Medium & -0.1 & -0.3 & -0.5 & -1.0 \\
$4 \mathrm{M} \mathrm{HCl}$ & - & - & $0.633(0.011)$ & 0.633 \\
& & & & $(0.013)$ \\
& & & & 0.220 \\
$4 \mathrm{M} \mathrm{HCl}$ & - & - & - & $(0.013)$ \\
& & & & 0.868 \\
& & & & $(0.024)$ \\
$0.1 \mathrm{M} \mathrm{Oxalic}$ & -0.520 & -0.321 & -0.420 & 0.168 \\
acid & $(0.046)$ & $(0.032)$ & $(0.036)$ & $(0.017)$ \\
& 0.042 & 0.115 & 0.124 & 0.114 \\
& $(0.014)$ & $(0.013)$ & $(0.011)$ & $(0.006)$ \\
& & 0.679 & & \\
& & $(0.038)$ & & \\
\hline
\end{tabular}

Standard deviation is written in brackets. Each value is the mean of five voltagramms Scan speed $10 \mathrm{mV} \mathrm{s}^{-1}$
The electrochemically reversible redox system of arsenic was previously described, and As (V) was reduced in the presence of hematite on a carbonaceous electrode under mild conditions, low acid concentration $(1 \mathrm{M} \mathrm{HCl})$ and moderate reducing potentials $(-1.0 \mathrm{~V})$. The iron oxide was reduced on the electrode and the formed $\mathrm{FeO}$ was dissolved. The Fe (II) generated during the pretreatment step reduced As (V) to As (III) due to the $\mathrm{pH}$ and reducing conditions used, followed by the reduction of $\mathrm{As}(\mathrm{III})$ to $\mathrm{As}^{\mathrm{o}}$ stripped on the anodic scan. Iron oxide has the same effect on the voltammograms of As (III) [20].

For the determination of total inorganic arsenic, the optimal SWV parameters were: Step height of $0.008 \mathrm{~V}$, amplitude of $0.040 \mathrm{~V}$, frequency of $150 \mathrm{~Hz}$ and $-0.8 \mathrm{~V}$ for $180 \mathrm{~s}$ as pretreatment step. The supporting electrolyte was $1 \mathrm{molL}^{-1} \mathrm{pH}=0$, the electrode was a modified carbon paste prepared by mixing carbon paste with $3 \%$ of hematite and silicone oil. The calibration was an addition standard with As (V): $2.91-5.58-11.9 \mathrm{mgkg}^{-1}$ as shown in Fig. 2. The response is linear up to 70 $\mu \mathrm{gL}^{-1}$, the limit of detection is $2 \mu \mathrm{g} \cdot \mathrm{L}^{-1}$ and the fitting regression coefficient is greater than 0.99. The supporting electrolyte used for the determination of $\mathrm{As}(\mathrm{III})$ was acetate/acetic acid buffer $0.1 \mathrm{M}$ with a pretreatment step at $-1 \mathrm{~V}$ 100s. The standard addition was with As (III): 3.56 - $6.79-13.5 \mathrm{mg} . \mathrm{kg}^{-1}$ shown in Fig. 3 [21].

To obtain well shaped peaks having reproducible potentials and intensities, it was necessary to apply a reduction potential of $-1.0 \mathrm{~V}$ for at least 10 seconds, followed by the corresponding square wave anodic scans. The optimum parameters were obtained by using synthetic samples prepared as described above. Optimization criterion was based on maximum peak height to peak width ratio. The optimized instrumental parameters were: amplitude $0.010 \mathrm{~V}$, step potential $0.008 \mathrm{~V}$ and frequency $150 \mathrm{~Hz}$. Voltammograms showed peaks for arsenic at $0.100 \pm 0.007 \mathrm{~V} \quad(\mathrm{n}=5)$ in $0.1 \mathrm{M}$ acetic acid-acetate buffer and at $0.054 \pm 0.005 \mathrm{~V}(\mathrm{n}=5)$ in $1 \mathrm{M} \mathrm{HCl}$. 


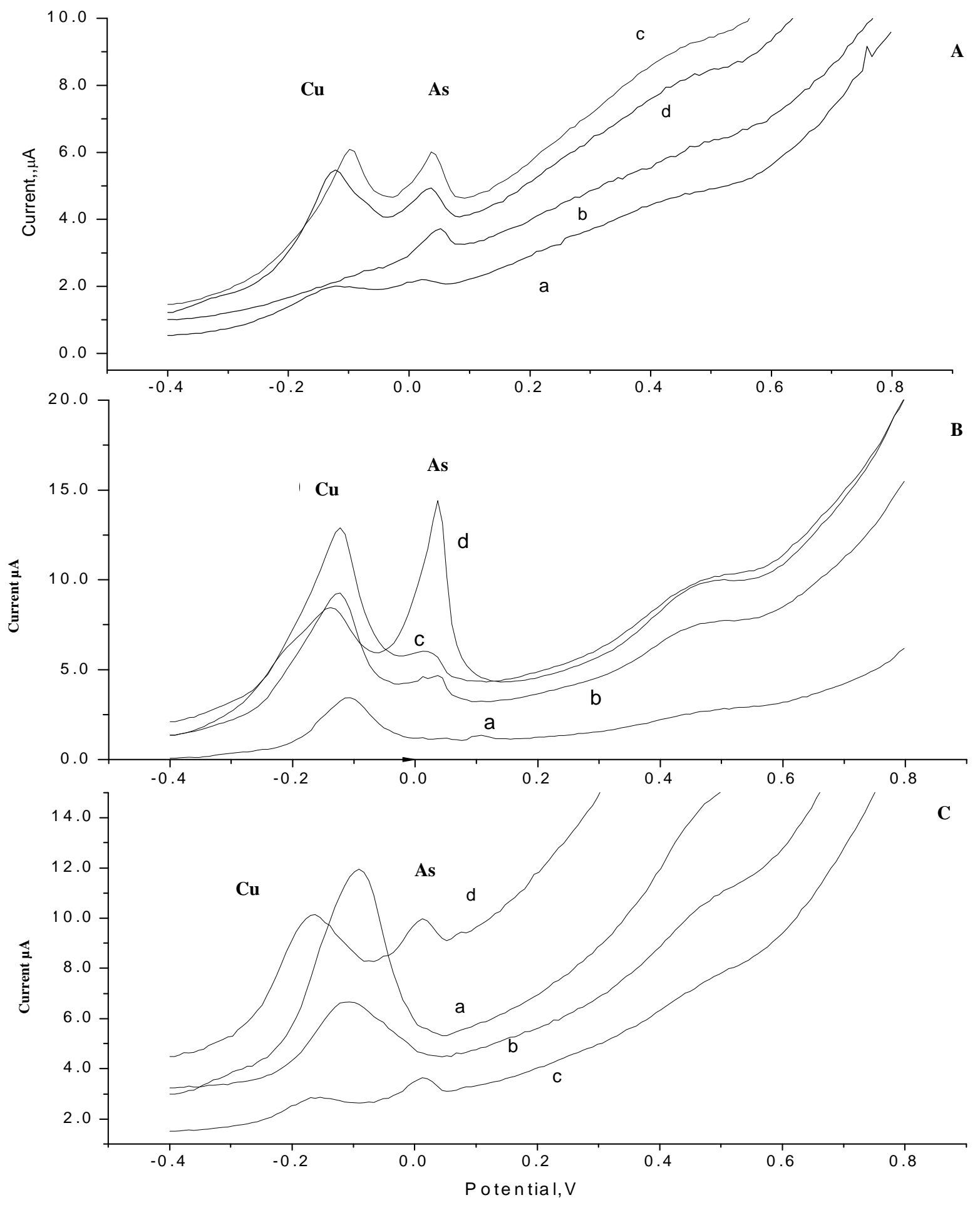

Figure 2. Voltammograms of total inorganic arsenic (a) Reference material CP1, (b) compost USRC3, (c) compost USRC6. Electrolyte: 1 M $\mathrm{HCl}$, Standard additions: (a) $0 \mathrm{mgkg}^{-1}$, (b) $2.91 \mathrm{mgkg}^{-1}$, (c) $5.58 \mathrm{mgkg}^{-1}$ and (d) $11.9 \mathrm{mgkg}^{-1}$ 


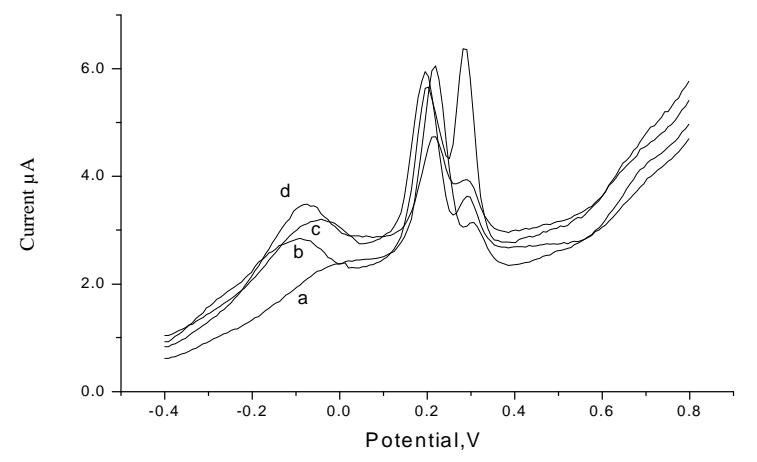

Figure 3. Voltammograms of As (III). Reference material CP1. Electrolyte: 0.1 M acetic acid/acetate. Pre-treatment: -1.0V, 100s. Standard additions: (a) $0 \mathrm{mgkg}^{-1}$, (b) $3.56 \mathrm{mgkg}^{-1}$, (c) $6.79 \mathrm{mgkg}^{-1}$ and (d) $13.5 \mathrm{mgkg}^{-1}$

More than $60 \%$ of the arsenic present in compost was inorganic, whose percentage was similar to that in urban compost and less than that in agricultural compost, whose procedures of treatment and composting were different. The obtained results show that the origin and composting process do not affect the proportion of inorganic arsenic in compost. The presence of As (III) was detected only in CP-1, and impossible detectable in urban composts due to low concentration $\left(<0.3 \mathrm{mgkg}^{-1}\right)$. Table 6 summarizes the concentrations of total lixiviate arsenic, inorganic arsenic and As (III) present in the leachate composts, where agricultural compost was mobilized as inorganic arsenic form and $2 \%$ of total arsenic present in the solid was as $\mathrm{As}(\mathrm{III})$ form. The composts from waste urban solids have different results, where USRC3 compost whose digestion before composting was anaerobic, have a percentage of inorganic arsenic (4\%) smaller than USRC6 compost (13\%). This difference may be associated to the stabilization of organic matter in USRC 3 compost, which contains humic acids 100 times higher.

Table 6. Total arsenic in lixiviates digested compost determined by ICP-MS compared to inorganic arsenic and As (III) determined in lixiviates compost by SWV.

\begin{tabular}{lcccccc}
\hline $\begin{array}{l}\text { Leach- } \\
\text { ate }\end{array}$ & $\begin{array}{c}\text { Total As } \\
\text { mgkg }^{-1}\end{array}$ & $\begin{array}{c}\text { Inorganic } \\
\text { As } \\
\text { mgkg }^{-1}\end{array}$ & $\begin{array}{c}\text { As(III) } \\
\text { mgkg }^{-1}\end{array}$ & $\begin{array}{c}\text { Total } \\
\text { As \% }\end{array}$ & $\begin{array}{c}\text { Inorg. } \\
\text { As \% }\end{array}$ & $\begin{array}{c}\text { As(III) } \\
\text { mgkg }^{-1}\end{array}$ \\
\hline CP-1 & $0.186 \pm$ & $0.115 \pm$ & $0.113 \pm$ & 3 & 2 & 2 \\
& 0.005 & 0.013 & 0.023 & & & \\
USRC3 & $0.894 \pm$ & $0.151 \pm$ & $0.464 \pm$ & 23 & 4 & - \\
& 0.010 & 0.021 & 0.045 & & & \\
USRC6 & $0.846 \pm$ & $0.379 \pm$ & $0.425 \pm$ & 30 & 13 & - \\
& 0.010 & 0.041 & 0.009 & & & \\
\hline
\end{tabular}

\section{Conclusion}

Because the toxicity varies in species of arsenic and depends on the redox state and the physicochemical form, it's of great importance the speciation of those different forms presents in composts and leachates. Two thirds of arsenic present in solid composts are in inorganic form, where $\mathrm{As}(\mathrm{III})$ was the minority component, detectable only in agricultural compost. In the other composts, the concentration of As(III) was less than $0.3 \mathrm{mgkg}^{-1}$. In the leachate composts, the inorganic arsenic was mainly mobilized as As(III) form. The mobilization of inorganic arsenic in compost may be influenced by the reduction nature of others components in compost, which will have serious environmental impact as As(III) toxic form.

\section{References}

1. J. Tyson, ISRN Analytical Chemistry, 24 (2013). https://doi.org/10.1155/2013/835371

2. Ming-Li Chen, Lin-Yu Ma, Xu-Wei Chen, Talanta, 125 (2014) 78. https://doi.org/10.1016/j.talanta.2014.02.037

3. B. S. Sheppard, W. L. Shen, J. A. Caruso, D. T. Heitkemper, F. L. Fricke, J. Anal. At. Spectrom., 5 (1990) 431. https://doi.org/10.1039/ja9900500431

4. X. Zei, C. A. Brockhoff-Schwegel and J. T. Creed, J. Anal. At. Spectrom., 16 (2001) 12. https://doi.org/10.1039/b004257i

5. Y. L. Feng, H. Y. Chen, L. C. Tian and H. Narasaki. Anal. Chim. Acta, 375 (1998) 167. https://doi.org/10.1016/S00032670(98)00285-2

6. F. Laborda, M. J. Baxter, H. M. Crews and J. Dennis, J. Anal. At. Spectrom., 9 (1994) 727. https://doi.org/10.1039/JA9940900727

7. A. D'Ulivo. Spectrochim. Acta B, 59 (2004) 793.

https://doi.org/10.1016/j.sab.2004.04.001

8. F. Laborda, E. Bolea and J. R. Castillo, Anal. Bioanal. Chem., 388 (2007) 743. https://doi.org/10.1007/s00216-006-1037-6

9. F. Laborda, E. Bolea and J. R. Castillo, $J$. Anal. At. Spectrom., 15 (2000) 103. https://doi.org/10.1039/a905270d 
10. B. Radke, L. Jewell and J. Namiesnik, Anal. Chem., 42 (2012) 162.

http://www.tandfonline.com/doi/abs/10.1080 /10408347.2011.634637

11. S. Miyashita, M. Shimoya and Y. Kamidate, Chemosphere, 75 (2009) 1065.

https://doi.org/10.1016/j.chemosphere.2009.0 1.029

12. K. Virender, L. Sharma and M. Sohn, Environ. Int., 35 (2009) 743. https://doi.org/10.1016/j.envint.2009.01.005

13. C. J. Langdon, T. G. Piearce and A. A. Meharg, Environ. Pollut., 124 (2003) 361. https://doi.org/10.1016/S02697491(03)00047-2

14. R. Singh, S. Singh, P. Parihar, P. V. Singh and S. M. Prasad, Ecotoxicol. Environ. Saf., 112 (2015) 247. https://doi.org/10.1016/j.ecoenv.2014.10.009

15. M. Bissena, H. Fritz and B. Frimmel, Acta Hydroch. Hydrob., 31 (2003) 9. https://doi.org/10.1002/aheh.200390025

16. J. H. T. Luong, E. Majid and K. B. Male. Open Anal. Chem. J., 1 (2007) 7. https://doi.org/10.2174/18740650007010100 07
17. S. Sanllorente-Méndez, O. DomínguezRenedo and M. J. Arcos-Martínez, Sensors, 10 (2010) 2119. https://doi.org/10.3390/s100302119

18. EPA Method, Microwave assisted acid digestion of sediments, sludges, soils and oils, US Environmental Protection Agency (1994) 3051.

19. D. S. Kosson, H. A. Van der Sloot, F. Sachez and A. C. Garrabrants, Environ. Eng. Sci., 19 (2002) 159. https://doi.org/10.1089/10928750276007918 8

20. G. Cepriá, S. Hamida, F. Laborda and J. R. Castillo J. Appl. Electrochem., 37 (2007) 1171.https://doi.org/10.1007/s10800-0079380-7

21. G. Cepria, S. Hamida, F. Laborda and J. R. Castillo, Anal. Lett., 42 (2009) 1. https://doi.org/10.1080/00032710903082713 